\title{
Implementation of Public-Private Partnership Models in the Field of Ecological Modernization of the Environmental Safety System
}

\author{
By Grygorii Kaletnik ${ }^{1}$, Svitlana Lutkovska ${ }^{2}$
}

\begin{abstract}
The article considers various forms of public-private partnership, which allow extensive use of private capital in solving many problems not only in the production of public goods and public services, production of natural monopolies, but also in providing natural and man-made and environmental security. It is determined that for the Ukrainian practice it is important to apply the best foreign experience in the implementation of innovative projects on the basis of public-private partnership (PPP). Positive foreign experience highlights the use of PPP in Ukraine as an alternative mechanism for financing innovative projects to implement and accelerate modernization transformations in the national economy. It is established that the implementation of PPP in Ukraine requires the formation of certain institutional conditions: definition of requirements to be met by operators wishing to enter the relevant industries, in particular: evidence of its financial security, evidence of its ability to operate; introduction of the project form of realization of the planned plans; substantiation of local selfgovernment bodies for choosing the form of involvement of the private sector; introduction of an effective system of control by local governments over the performance of current functions and investment obligations by private operators; development of requirements for the reporting system of a private operator; involvement in decision-making on the transfer of infrastructure to the private sector, as well as determining the frequency and types of public control; development and implementation of a mechanism for determining the liability of private sector representatives for causing damage to the property of territorial communities by their actions or inaction and, conversely, determining a mutually acceptable mechanism for return of invested funds, etc. The PPP mechanism forms the basis for the joint responsibility of the state, community and business for the development of sectors that have priority for the regional economy, environmental protection, development of territorial communities.
\end{abstract}

Keywords: public-private partnership, public-private partnership, ecological and economic development, ecological modernization, sustainable development

\section{Introduction}

In world practice, public-private partnership aims to attract private investment (both domestic and foreign) on long-term terms to finance and manage public infrastructure. The choice of the initial direction of use of the specified mechanism depends first of all on economic and social levels of development of the country or a

| ${ }^{1}$ Doctor of Economics, Professor, Academician of NAAS of Ukraine, Head of the Department of Administrative Management and Alternative Energy Sources, Vinnytsia National Agrarian University, Vinnitsia, Ukraine

${ }^{2}$ Candidate of Pedagogical Sciences, Associate Professor, Vice-rector for Scientific and Pedagogical Work, 
certain area.

It is important for Ukrainian practice to apply the best foreign experience in the implementation of innovative projects on the basis of public-private partnership (PPP). Positive foreign experience of public-private partnership in innovative economic development, insufficient innovation activity and lack of funds for innovation in Ukraine, actualizes the use of PPP as an alternative mechanism for financing innovative projects to implement and accelerate modernization in the national economy.

The variety of forms of public-private partnership allows extensive use of private capital in solving many problems not only in the production of public goods and public services, production of natural monopolies, but also in the field of natural and man-made and environmental safety. In these areas, the state can not give up its presence and to resolve the contradictions between the limited capacity of the state budget and the need to invest capital to ensure the reproduction and development of strategic and social significance of these areas uses public-private partnership.

\section{Literature Review}

Particular attention of domestic and foreign scientists is paid to environmental issues that shape environmentally friendly sustainable development. Worth noting are the works of Kaletnik G.M [10, 11], Shilepnytsky P.I [14], Kozlovsky S.V [12], Hvesika M.A [9], Ilyashenko O.I etc. Research by Rassadnikova S. [7], Garbarinina V. [2] is devoted to the introduction of PPP mechanisms for the development of ecological infrastructure.

The purpose of the article is to study the processes of implementation of public-private partnership models in the field of ecological modernization of the ecological and economic security system.

\section{Methodology}

The analysis of the institutional support of public-private partnership shows that the foundations of the legal framework of the PPP are currently being formed in Ukraine. The main provisions of the legal framework for cooperation between the state and business have not become a catalyst for the development of incompleteness, but also imperfection. The system of PPP institutional infrastructure is currently absent in Ukraine $[1$, p. 2].

Thus, in order for public-private partnership to be implemented in our country, it is necessary to form certain institutional conditions. Such conditions include: determination of the requirements to be met by operators wishing to enter the relevant industries, in particular: regarding evidence of its financial security, evidence of its ability to carry out operational activities; introduction of the project form of realization of the planned plans; substantiation of local self-government bodies for choosing the form of private sector involvement; introduction of an effective system of control by local governments over the performance of current functions and investment obligations by private operators; development of requirements for the reporting system of a private operator; involvement in decision-making on the transfer of infrastructure facilities to the private sector, as well as determining the frequency and types of public control; development and 
implementation of a mechanism for determining the liability of private sector representatives for causing damage to property of territorial communities by their actions or inaction and, conversely, determining a mutually acceptable mechanism for return of invested funds, etc. [1, p. 2-3].

Cooperation between the public and private sectors in the field of environmental security is a special form of PPP, which is specifically designed to improve crisis management through joint coordination and cooperation between private and public representatives. Within this PPP model, the commercial supply chain of basic goods and services complements the supply chain of public services in such a way as to alleviate the crisis situation. Unlike other approaches, the purpose of the PPP is not to maximize total profits, but to minimize the cost by considering the state budget constraint and limiting the participation of the private enterprise. The main task in these conditions is to improve the crisis management process.

In the environmental field, cooperation between the state and the private owner is aimed at implementing projects to implement "green" technologies, mitigate the effects of environmental change, development of the recreational sphere. In the future, publicprivate partnerships have the opportunity to continue to build effective relations between public authorities and local governments, businesses and non-profit private organizations to perform the necessary public functions. The combination of the best opportunities of partners in project management in the field of security increases the resilience of critical infrastructures, strengthens the degree of mutual trust of public and private entities and improves security indicators in the state [13-15, p. 224-232].

\section{Case Studies}

Public-private partnership is a special form of cooperation aimed at organizing cooperation under the scheme "Business - government - community", where the public exercises its right to control the executive, social institutions, socially oriented business, environmentally hazardous industries and more. Some forms of PPP can be defined as management contracts. The private partner takes over the management of the state object for the period determined by the agreement, when the property and investment rights remain with the state.

Concession forms provide for state-initiated construction or reconstruction of a facility by a private investor at their own expense. The subject of concession agreements is state (municipal) property and public (public) services. The state is one of the subjects of the concession agreement, under which the object is transferred to the concession for a certain period on paid terms and is subject to return upon expiration of the agreement into state ownership. These models often relate to transport communications, health, education, etc. [9, p. 342-348].

PPP agreements, which require the creation (construction) of new facilities (Greenfield project), provide that the private partner independently or jointly with the state participates in the construction and management of the newly created facility for the period specified in the project agreement. The private entity assumes most of the financial and operational risk and returns its investment throughout the life of the project. The concession type of contracts has several types: 
«BOT» (Build, Own, Operate, Transfer - construction, possession, operation / management, transfer). According to this model, the private partner receives the right to use and own the object during the term of the agreement, after which the object is transferred to the authorities.

«BLOT» (Build, Lease, Operate, Transfer - construction, lease, operation, transfer). A business entity receives a deductible for the financing, design, construction and operation of a leased property (as well as the collection of funds from those who receive services) during the lease period, by paying a fee for use.

* "BOT" (Build, Operate, Transfer - construction, operation / management, transfer). Under this model, according to the infrastructure development agreement, the private owner uses the facility, taking risks. During operation, the private owner may have the right of ownership within the scope of the agreement. After the expiration of the agreement, the right of ownership passes to the state.

* "SBI" (Build, Own, Operate - construction, ownership, operation / management). The private owner is authorized to finance, build, own, operate the facility. The state buys the services of the object, providing the investor with a minimum income.

* "WTO" (Build, Transfer, Operate - construction, transfer, operation / management). This model provides for the transfer of the object to the state after the construction is completed, but in the future the object can be again given for use to a private owner.

* "VOMT" (Build, Operate, Maintain, Transfer - construction, operation / management, maintenance, transfer). This model delegates responsibility to the private party for the maintenance and repair of infrastructure facilities built by it.

* "DVOOT" (Design, Build, Own, Operate, Transfer - design, construction, ownership, operation / management, transfer). The agreement places the responsibility on the private owner on the design and construction stage.

«DVFO» (Design, Build, Finance, Operate - design, construction, financing, operation / management). This model regulates the responsibility of the private party for financing the construction of infrastructure facilities.

* "VVO" (Bay, Build, Operate - acquisition, construction, operation). The agreement provides for the sale of assets for modernization and improvement of property and operation for a certain period of time. State control is exercised during the term of the property transfer agreement.

* «BLT» (Build, Lease, Operate - construction, lease, transfer). The agreement, according to which the private owner finances and builds the object, under the lease agreement operates the object, accepting all risks, after the expiration of the agreement transfers the ownership to the authorities.

Agreements that provide for the restoration of property (Brownfield contact) are economically similar to the Greenfield project, but instead of creating a new asset, the private entity takes over the existing asset and improves (restores) it: reconstructs, modernizes or expands. Such projects include the following models:

* "ROT" (Rehabilitate, Operate, Transfer - restoration (reconstruction), operation, transfer). The object is transferred to a private owner for restoration, operation and transfer to the state.

* "RLT" (Rehabilitate, Lease or Rent, Transfer). A project in which a private owner 
restores an object, leases or leases it to a state owner, and then transfers it to the state.

«BROT» (Build, Rehabilitate, Operate and Transfer - construction, restoration (reconstruction), management, transfer). The private owner restores the facility or completes the partially constructed facility, operates it during the term of the agreement and returns it to the state [13].

In the field of increasing the level of natural and man-made and environmental safety, forms of PPP can be used to create, namely:

- partnerships formed to attract the managerial expertise of a private partner for the implementation of large and complex programs;

- partnerships, the priority of which is to attract new technologies developed in the private sector;

- partnerships that aim to attract a variety of financial resources available to business [11, p. 16-25].

Public-private partnership (PPP) is recognized in world practice as a key tool for solving important problems of sustainable development at the regional and local levels. Orientation of strategic plans exclusively on the use of budget funds does not allow the government to implement large-scale strategic projects that shape the competitiveness of territorial socio-economic systems. Due to the involvement of private operators in the implementation of strategies, it becomes possible to release part of the budget to direct them to other priority areas of sustainable development, as well as attracting to the public sector experience and business approaches of the private sector [13; 15, pp.176-181].

However, for private companies in the current socio-economic conditions, the financial attractiveness of scientific and technical PPP projects may be insufficient. Long implementation period, low level of profitability, high risks in the public services market limit innovative development. As part of the development of basic sciences and a set of technologies of a strategic nature, the state and the private sector have their own specializations and advantages, with the combination of which this cooperation is formed and a synergy effect is created. The triplicity of the system consists in the presence of three main components, without which it is impossible to imagine the innovation process: the state (represented by public authorities), science (represented by scientific subjects) and business (represented by business entities). The joint work of science, business and government in the implementation of PPP projects will promote the development of innovative forms of project financing, stimulate entrepreneurial thinking and promote the introduction of advanced management methods in government. At the same time, initiatives aimed at overcoming the existing problems of development of science and technology and stagnant trends in entrepreneurship are of a strategic nature [4; 10, p. 3-11].

The development of Ukraine's regions is constrained by the low institutional, investment and financial capacity of local governments to address economic, environmental and social issues. The majority of all local budgets are unable to ensure the full and effective implementation of local governments' statutory functions and powers. The lack of sufficient own financial and material base in most local budgets weakens the investment capacity of communities and their associations, hinders the attraction of investment resources in infrastructure development [12, p. 54-64; 16, c. 52-64].

The small population of most territorial communities leads to their financial and economic 
insolvency, lack of reserves and resources for their own economic development. The economic insolvency of sparsely populated territorial communities deprives them of opportunities for development both in terms of growth of economic activity in them, and in terms of creating their own normal living conditions for residents [5; 8, p. 4-7].

Foreign and domestic practice shows that the solution to the problems of territorial communities, in particular the problem of waste (household), it is advisable to look not at the state but at the municipal level. Developing a successful waste disposal program for most local communities is complicated by the small number and density of people living in a given region, low tax base, limited local budgets and qualified staff, and a small number of private business sectors. Abroad, it is due to the high level of self-organization of territorial communities (municipalities) that it has become possible to implement a number of rather costly infrastructure projects for waste recycling, which are implemented, including the use of the PPP mechanism.

The PPP mechanism forms the basis for the joint responsibility of the state, community and business for the development of sectors that have priority for the regional economy, environmental protection, development of territorial communities.

In general, in some EU countries, every tenth project implemented in a public-private partnership is aimed at ensuring the environmental component of sustainable social development.

This is especially true for waste management, in particular household waste, as there are significant problems in this area, not least due to underfunding of the sector. The example of European countries demonstrates the effective use of the PPP mechanism to address the problem of waste.

PPP's foreign experience shows a significant variety of forms of partnership, which in general can be divided into two categories: contractual and institutional. This is a clear example of a formal approach, which permeates domestic "reporting" on "performance" in the field PPP / concessions [4].

Table 1: Generalized characteristics of contractual forms of PPP

\begin{tabular}{|l|c|c|c|c|c|}
\hline Form of PPP & $\begin{array}{c}\text { Ownership } \\
\text { of assets }\end{array}$ & $\begin{array}{c}\text { Operation and } \\
\text { maintenance }\end{array}$ & $\begin{array}{c}\text { Capital } \\
\text { investments }\end{array}$ & $\begin{array}{c}\text { Commercial } \\
\text { risk }\end{array}$ & $\begin{array}{c}\text { Estimated } \\
\text { duration, } \\
\text { years }\end{array}$ \\
\hline Service contract & state & $\begin{array}{c}\text { Public/ } \\
\text { private }\end{array}$ & $\begin{array}{c}\text { Public/ } \\
\text { private }\end{array}$ & state & $1-2$ \\
\hline $\begin{array}{l}\text { Contract for the provision of public } \\
\text { services and works }\end{array}$ & state & Public/private & private & state & $3-4$ \\
\hline Management contract & state & private & state & state & $3-5$ \\
\hline $\begin{array}{l}\text { Contract for investment or } \\
\text { construction }\end{array}$ & $\begin{array}{c}\text { public and } \\
\text { private }\end{array}$ & private & private & private & $20-30$ \\
\hline Technical assistance contract & $\begin{array}{c}\text { public and } \\
\text { private }\end{array}$ & private & $\begin{array}{c}\text { Public/ } \\
\text { private }\end{array}$ & collective & $5-15$ \\
\hline $\begin{array}{l}\text { Contract for the execution of the order } \\
\text { (supply of products for government } \\
\text { needs) }\end{array}$ & $\begin{array}{c}\text { public and } \\
\text { private }\end{array}$ & private & private & private & $1-2$ \\
\hline Contract for operation and transfer & state & private & state & collective & $3-5$ \\
\hline Contract after privatization support & $\begin{array}{c}\text { public and } \\
\text { private }\end{array}$ & $\begin{array}{c}\text { joint } \\
\text { operation }\end{array}$ & $\begin{array}{c}\text { Public/ } \\
\text { private }\end{array}$ & collective & $3-10$ \\
\hline
\end{tabular}

Source: developed by the author based on [2-3] 
It is proposed to develop a single methodology for evaluating investment projects of public-private partnership (with clear criteria and procedures for determining the feasibility of projects, justification of fiscal risks of projects, etc.) in order to prevent such situations, increase the validity of PPP projects. At the same time, the central and local executive bodies in the field of waste management have identified 33 facilities for which it is planned to implement projects using the mechanism of PPP [4]. At the same time, due to the decentralization process, the PPP mechanism will become popular among local communities. In particular, in Manly, Zhytomyr region, a project was implemented to convert thermal boilers from gas consumption to local wood waste, which reduced the cost of payment by several budgetary institutions from UAH 2,200 per 1 GC to UAH 850 per 1 GC [5].

Given that the aggravation of environmental problems require immediate action to achieve ecological balance, development and reconstruction of environmental infrastructure and environmental modernization, which, in turn, requires a significant amount of funding and large-scale investment, a real mechanism for attracting additional funding and sources of investment in Ukraine is the connection of the private sector to solve these problems [6]. The development of PPP mechanisms based on the principles of formation of investment attractiveness of ecological infrastructure objects is a promising direction of its effective development in modern conditions (Table 2).

Table 2: The main expected effects from the implementation of PPP mechanisms in the development of environmental infrastructure

\begin{tabular}{|c|c|c|}
\hline $\begin{array}{l}\text { Type of PPP } \\
\text { effect }\end{array}$ & Characteristics of the main components & $\begin{array}{l}\text { Areas of } \\
\text { manifestation }\end{array}$ \\
\hline Economic & $\begin{array}{l}\text { Improving the welfare, competitiveness of the economy, the } \\
\text { level of environmental and goods and services, reducing } \\
\text { budget expenditures, investment climate, the development of } \\
\text { environmental entrepreneurship }\end{array}$ & \multirow{7}{*}{$\begin{array}{c}\text { State } \\
\text { Business } \\
\text { People } \\
\text { Non- } \\
\text { governmental } \\
\text { organizations } \\
\text { and } \\
\text { other } \\
\text { institutions } \\
\text { public } \\
\text { society }\end{array}$} \\
\hline $\begin{array}{l}\text { Economic and } \\
\text { environmental }\end{array}$ & $\begin{array}{l}\text { Reduction of economic losses from pollution, resource } \\
\text { intensity, growth of fixed environmental funds, increase in } \\
\text { the amount of natural capital, increase in investment, } \\
\text { provision of natural assets }\end{array}$ & \\
\hline Ecological & Improving the environment, reducing environmental risks & \\
\hline $\begin{array}{l}\text { Political and } \\
\text { economic }\end{array}$ & $\begin{array}{l}\text { Improving the ecological image of the country, gaining access } \\
\text { to loans from international financial organizations }\end{array}$ & \\
\hline Social & $\begin{array}{l}\text { Improving human living conditions, improving the health of } \\
\text { the population, improving the level and quality of life, } \\
\text { reducing morbidity and mortality }\end{array}$ & \\
\hline Synergetic & $\begin{array}{l}\text { Integral economic effect from interaction and mutual } \\
\text { strengthening of action at crossing of factors and all } \\
\text { components of type of effect }\end{array}$ & \\
\hline External & $\begin{array}{l}\text { External effects are manifested in related activities and } \\
\text { sectors of the economy }\end{array}$ & \\
\hline
\end{tabular}

Source: developed by the author based on [7-8]

At the same time, it is worth emphasizing the existence of a number of obstacles to the active and large-scale implementation of PPP mechanisms for the development of 
environmental infrastructure. In particular, as was established by the study of Rassadnikova SI back in 2012 [7, p. 133-142], we are talking about the following:

- lack of theoretical foundations and achievements, methodological basis for the development, implementation and implementation of PPP for the development of environmental safety through modernization;

- unfavorable investment and business climate in the country;

- the budget deficit does not create an investment-innovative and financial basis for the development of environmental infrastructure and nature management, the state needs to attract significant financial, investment, material and other resources from various sources, the private sector, which has no strong incentives to invest;

- insufficient level of trust between government and business, negative experience in providing preferences, guarantees, benefits, state support for the private sector of the economy, which is not built on a long-term basis;

- high risk and cost of projects for the formation of environmental infrastructure.

The development and effective tools to combat today's security threats require the participation and joint action of all actors - government, the private sector and citizens. The public and private sectors are working together to prepare risk assessments, and the public sector is disseminating best practices for further action. The private sector can help the public by creating expertise for efficient resource allocation [13].

\section{Discussion and Conclusions}

It should be noted that the identified obstacles to the implementation of PPP mechanisms for the development of environmental modernization have not been eliminated, however, as well as the lack of information base and statistical observations on the financing of environmental infrastructure in the country and by business entities. It is obvious that the state thus does not use the potential of PPP mechanisms in the formation of environmental infrastructure, and thus - leaving at the level of declarations the implementation of the main goals and objectives of environmental policy, green economy, achieving a model of sustainable development.

Thus, as a result of scientific research we proposed forms and methods of implementing models of public-private partnership in the field of modernization of environmental safety as a special form of cooperation aimed at organizing cooperation under the scheme "business - government - community": involvement of management expertise large and complex programs and finances available for business; introduction of new, investmentintensive technologies; joint monitoring and control over the implementation of modernization processes.

It is established that in the ecological direction the cooperation of the state and the private owner is directed on projects concerning introduction of "green" technologies, mitigation of consequences of ecological changes, development of recreational sphere. In the long run, combining the best opportunities of partners in security project management will increase the resilience of critical infrastructures, strengthen the degree of mutual trust between public and private entities and improve security indicators in the state. It is proved that the introduction and development of mechanisms of public-private partnership in the field of modernization is associated with the need for significant 
investments to increase the competitiveness of the economy, attract private sector resources for infrastructure projects, public services.

\section{References}

Zakon Ukrainy «Pro derzhavno-pryvatne partnerstvo» no. 2404-VI vid 01.07.2010 r. iz zmin. ta dopov. URL: http://zakon.rada.gov.ua/laws/show/2404-17 (data zvernennia: 24.03.2020) [in Ukrainian].

Harbarynina V. Pidvyshchennia rivnia instytutsiinoi spromozhnosti orhaniv publichnoi vlady $\mathrm{v}$ umovakh realizatsii polityky derzhavno-pryvatnoho partnerstva. V. Harbarynina. Efektyvnist derzhavnoho upravlinnia, 2016. Ch. 1. Vyp. 1/2 (46/47). P. 180-187.

Normatyvno-pravova baza DPP. URL: http://www.me.gov.ua/Documents/Detail?lang=uk$\underline{\text { UA\&id }=\text { c5fe4de5-3213-413e-ac82-71 fef98f6933\&title=OznakiDerzhavnoprivatnogoPartnerstva }}$ (data zvernennia: 26.03.2020) [in Ukrainian].

Vysnovky za rezultatamy analizu efektyvnosti zdiisnennia DPP. URL: http://www.me.gov.ua/Documents /DetailPlang=uk-UA\&id=9a47d67e-6546-4caa9ab0dce86654169e\&title=SistemaZboruTaUtilizatsii BiogazuNaPoligoniTverdikhPobutovikhVidkhodivVM-Kremenchuk (data zvernennia: 27.03.2020) [in Ukrainian].

Stan zdiisnennia DPP v Ukraini. URL: http://www.me.gov.ua/Documents/Detail?lang=ukUA\&id=62a9b6fb-27ff-462a-b351-eeeadfb26b6f\&title=StanZdisnenniaDppVUkraini (data zvernennia: 27.03.2020) [in Ukrainian].

Public Private Partnership: A Guide for Local Government. URL: British Columbia Ministry of Municipal Affairs. Mode of access: http://www.cscd.gov.bc.ca (data zvernennia: 28.03.2020) [in Ukrainian].

Rassadnykova S.I. Derzhavno-pryvatne partnerstvo u rozbudovi ekolohichnoi infrastruktury: stanovlennia, osoblyvosti, investytsii. S.I. Rassadnykova. Ekonomika: realii chasu, 2012. No. 1 (2). P. 133-142.

Holian V. Derzhavno-pryvatne partnerstvo yak bazova instytutsionalna peredumova kapitalizatsii pryrodnykh resursiv v umovakh detsentralizatsii. Ekonomist, 2015. No. 9. P. 4-7.

Publichno-pryvatni formy zabezpechennia staloho prostorovoho rozvytku Ukrainy: [za nauk. red. akad. NAAN Ukrainy, d.e.n., prof. M. A. Khvesyka]. Derzhavna ustanova «Instytut ekonomiky pryrodokorystuvannia ta staloho rozvytku Natsionalnoi akademii nauk Ukrainy». K. : DU IEPSR NAN Ukrainy, 2019. 650 p.

Kaletnik G. M., Zabolotnyi G. M., Kozlovskyi S. V. (2011). "Innovative models of strategic management economic potential within contemporary economic systems". Actual Problems of Economic. v l, 4(118), pp. 3-11.

Kaletnik G., Lutkovska S. Modern organizational and Economic Mechanism for Environmental Safety. Journal of Environmental Management and Tourism, (Vol XI, Summer), 2020. PP. 606-612.

Koziuk V., Hayda Y., Dluhopolskyi O., Kozlovskyi S. (2020). "Ecological performance: ethnic fragmentation versus governance quality and sustainable development". Problemy ekorozwoju - Problems of sustainable development. vol. 15(1), pp. 53-64 URL: https://ekorozwoj.pollub.pl/no29/h.pdf (Аата звернення 01.04.2020).

Lutkovska S.M. Formalizatsiia publichno-pryvatnoho partnerstva u sferi modernizatsii ekolohichnoi bezpeky. Mizhnarodnyi naukovyi zhurnal "Internauka", 2020. V 5(37). PP. 9-17.

Shylepnytskyi P.I. Derzhavno-pryvatne partnerstvo: teoriia i praktyka. P. I. Shylepnytskyi; Nats. akad. nauk Ukrainy, In-t rehion. doslidzh. Chernivtsi : [b. v.], 2011. 454 p.

Derzhavno-pryvatne partnerstvo v systemi rehuliuvannia ekonomiky. [Yefymenko T. I. ta in.] ; za zah. red. chl.-kor. NAN Ukrainy T. I. Yefymenko ; Nats. akad. nauk. Ukrainy, DU "In-t ekonomiky ta prohnozuvannia". K. : [b. v.], 2012. 371 p.

Berezyuk S., Tokarchuk D. and N. Pryshliak. Economic and Environmental Benefits of Using Waste Potential as a Valuable Secondary and Energy Resource. Journal of Environmental Management and Tourism, Volume X, Spring, 2019. 